\title{
Research on the evaluation system of green highway in the whole life cycle of South China Mountain Area
}

\author{
Shengjun $\mathrm{YU}^{1,2}$, Jiang $\mathrm{Li}^{1,2^{*}}$ and Chenhui Feng ${ }^{3}$ \\ ${ }^{1}$ Research Institute of Highway Ministry of Transport, Beijing 100088, China \\ ${ }^{2}$ Key Laboratory for Road Structure \& Material of Ministry of Transport, Beijing 100088,China; \\ ${ }^{3}$ Beijing Municipal Engineering Consulting Corporation, Beijing, China,100124
}

\begin{abstract}
The urgency of the global environmental impact has made mankind pay more and more attention to the issue of sustainable development in all fields. The field of highway construction is no exception. Traditional highway construction has the characteristics of high investment, high energy consumption, wide pollution and strong destruction, and serious environmental impact, which is not conducive to the long-term development of society and the country. From the point of view of life cycle, combined with Current Events and Policies, green concept, Four-New Technology and consulting experience in highway construction of many years, this paper puts forward a three-stage green highway construction system of green design, green construction and green road maintenance. to promote the healthy, sustainable and green development of highway industry.
\end{abstract}

\section{Introduction}

With the continuous improvement of national economy and comprehensive national strength, socialism with Chinese characteristics has entered a new era. The main social contradictions have transformed from the contradiction between the people's growing material and cultural needs and backward social production to the contradiction between the people's growing needs for a better life and the uneven and inadequate development. China has stepped into the process of "accelerating the reform of ecological civilization system and building a beautiful China". Highway construction belongs to the field of transportation infrastructure construction, no exception. It is developing from the traditional highway construction to the green highway with higher environmental protection requirements.

At the beginning of this century, the theme forums of "comprehensive, coordinated and sustainable development of China's transportation" and "taking the road of energy conservation and environmental protection, building green transportation" held in Beijing marked the new development stage of China's Green Road related research.

Since the 18th and 19th National Congress of the Communist Party of China, the Ministry of transport has attached great importance to the green development, circular development and low-carbon development of highways, issued a series of relevant policy opinions, and actively organized the construction of a number of typical green highway demonstration projects.

In May 2013, the Ministry of transport issued the guiding opinions on accelerating the development of green circulation and low carbon transportation, which proposed that by 2020 , on the premise of ensuring the realization of the carbon emission target per unit GDP determined by the State Council, the awareness of green circulation and low carbon development of the whole industry will be significantly enhanced, the energy conservation and emission reduction mechanism will be more perfect, the driving capacity of scientific and technological innovation will be significantly improved, the level of supervision will be significantly improved, the efficiency of energy and resource utilization in the industry will be significantly improved, the control of greenhouse gas emissions will achieve significant results, the ability to adapt to climate change will be significantly enhanced, the ecological protection will be fully implemented, the environmental pollution will be effectively controlled, the green circulation and low-carbon transportation system will be basically built, the laws, policies and standards for green circulation and low-carbon development of the transportation industry should be basically improved, and the industry energy consumption monitoring and assessment system should be basically established.

In August 2016, the Ministry of transport issued the guidance on the implementation of green highway construction, which clearly proposed that we should strengthen the research on green highway technology, vigorously carry out the research and development of key technologies of green highway, formulate green highway standards and specifications, revise relevant standards and specifications of green highway construction, improve the establishment of green highway construction evaluation index system, and clarify the technical requirements To

\footnotetext{
*Corresponding author's e-mail: jiang.li@rioh.cn
} 
guide the construction of green roads in an all-round way and encourage all localities to formulate evaluation standards for green roads with local regional characteristics.

In April 2017, a total of 33 typical demonstration projects of green highway construction were implemented. The Ministry of transport pointed out that it is necessary to make the demonstration content real, highlight the highlights of the demonstration, strengthen the demonstration guidance, constantly summarize experience, strengthen experience exchange, and comprehensively improve the level of highway construction.

In May 2018, the Ministry of transport issued the technical requirements for assessment of green transportation facilities Part one: Green Road, which is the first recommendation standard related to green road in the industry. The standard puts forward the generally accepted concept of green road life cycle and the definition of green design, green construction, green maintenance, etc., and at the same time, it also gives 7 sub item Green Road evaluation methods, such as green concept, ecological environmental protection, resource conservation, energy conservation and low carbon, quality construction, safety wisdom and service improvement.

Road engineering technicians, relevant experts and scholars have also actively carried out exploration and research for many years.

In 2004, Chen Hong et al. Took the coordinated development of ecological, economic and social benefits as the goal, integrated the design and construction of the highway with the natural environment, and formed a safe, comfortable, efficient and convenient belt road traffic ecosystem and regional traffic ecosystem with complete and harmonious landscape [1].

In 2011, Zhang Qin proposed that green highway refers to a road that can save resources, protect environment and reduce pollution to the greatest extent, bring smooth, comfortable and safe experience for drivers and passengers, and coexist harmoniously with nature under the guidance of sustainable development concept in the whole life cycle of the road[2].

In 2014, Wang Ji et al. Through analyzing the idea of life-cycle high way and the concept of green low-carbon highway as well as combining the idea of life cycle with the construction of green low-carbon highway, the paper expatiates on the methods of energy conservation and emission reduction in each stage of highway construction with a case study of the construction of green low-carbon Maliuwan-Zhaotong Expressway, and demonstrates the necessity of building green low-car bon highway with the idea of life cycle [3].

In 2015, Wang Chao-hui proposed to save resources, protect the environment and reduce pollution to the maximum extent within the life cycle of the road, and provide an ecological urban road with healthy, comfortable and efficient use environment [4].

The development of green highway is not only the internal requirement of highway industry, but also the inevitable requirement of the development of the times. In this regard, this paper systematically combs the existing green road construction experience, and complies with the national and industrial policies. At the same time, combined with the characteristics of South China mountain area, it makes a systematic study on the evaluation of green road construction technology system in Guangdong Province, and its results will be of great significance for the guidance of green road construction in South China mountain area.

\section{2 environmental characteristics of highway in South China Mountain Area}

\subsection{Characteristics of natural environment}

\subsubsection{Climate and environment}

South China mainly includes Guangdong Province, Guangxi Zhuang Autonomous Region, Hainan Province and Hong Kong and Macao Special Administrative Region. Most of the area is located in the middle and low latitudes. The average temperature in the coldest month is $\geq 10{ }^{\circ} \mathrm{C}$, the extreme minimum temperature is $\geq 4{ }^{\circ} \mathrm{C}$, and the days when the average daily temperature is $\geq 10^{\circ} \mathrm{C}$ are more than 300 days. It is a tropical subtropical region with high temperature and rainy, evergreen seasons.

There is abundant precipitation in this area, rainstorm is a common form of precipitation, but the annual precipitation is distributed unevenly, which is multicenter distribution. The annual precipitation in most places is $1400-2800 \mathrm{~mm}$. The rainfall is hot and rainy in the same season. The precipitation is mainly concentrated in April to September. It is one of the areas with the most abundant light, heat and water resources in China. At the same time, affected by the tropical monsoon and tropical cyclones, disastrous weather (rainstorm, Super Rainstorm) occurs frequently in this region, especially in July September of midsummer and early autumn, 40\% - 70\% of the precipitation in the coastal areas of Guangdong and Fujian is typhoon.

Therefore, the green highway construction in South China should meet the requirements of high temperature anti rut and smooth drainage.

\subsubsection{Hydrology and geomorphology}

The rivers in South China are dense, crisscross and rich in flow. The Pearl River system is rich in water. Its annual runoff is only second to that of the Yangtze River, about 67 times that of the Yellow River. Because of the rainy season of half a year or so, the flood season of the river is long, and the runoff changes have the characteristics of sudden rise and fall.

The hills are widely distributed in this area, with strong surface erosion and cutting. The mountainous hills account for more than $70 \%$ of the land area, and the low hills are the most common, and the distribution is less than $500 \mathrm{~m}$. The terrain decreases from northwest to Southeast, Wuyi Mountain, Daiyun Mountain, Boping Mountain, and Nanling Mountain in Guangxi, Guangdong Province are interlaced, and the landform is complex and diverse.

Therefore, the green highway in South China should 
consider the reasonable requirements of bridge and tunnel instead of road.

\subsubsection{Resources and environment}

South China is rich in plant resources and has a wide range of species, including tropical rain forest, seasonal rain forest and subtropical monsoon evergreen broad-leaved forest. It is dominated by subtropical families and genera, with an ancient origin and many rare and precious species. Therefore, many environmentally sensitive areas have been formed, such as forest parks, nature reserves, ecological strict control areas, etc.

In this area, there are many river systems, large surface runoff, rich water resources and aquatic resources. At the same time, there are many aquatic resource reserves and water body reserves.

Therefore, the green highway in South China should meet the requirements of green route selection and environmental protection, and be incorporated into regional tourism and cultural characteristics.

\subsection{Characteristics of human environment}

\subsubsection{Policy environment}

In order to promote the construction of green roads, the Ministry of transport formulated the guidance on the implementation of green road construction in 2016. On the basis of in-depth summary of previous work results, combined with the current national strategy and the requirements of green traffic development, in accordance with the system theory and the thought of cycle cost, the guiding opinions are based on the project quality, safety, durability and service, adhere to the "two overall plans", grasp the "four elements", the guiding opinions promote the transformation and upgrading of highway construction and development by means of concept improvement, innovation guidance, demonstration drive and system improvement. And implement the "five major tasks" of Green Road, highlight the special action of green road construction, continue to promote pilot demonstration, and create new highlights of road construction.

Guangdong Province, as the leading province of green road construction, attaches great importance to ecological civilization construction and makes every effort to promote green road construction. It plans to establish the performance evaluation system of green highway construction in Guangdong Province by 2020. The concept of green highway construction has been thoroughly implemented in the whole process of planning, design, construction, operation, management and service. A number of green highway construction pilot demonstration projects and science and technology demonstration projects have been completed, forming a long-term mechanism of green highway construction, and the green highway construction in Guangdong Province has made remarkable progress Exhibition.

\subsection{Human environment}

South China has a large population and a dense industry. Roads, railways and waterways intersect vertically and horizontally, and the traffic composition is diverse. At the same time, it is also the region with the largest population of foreign provinces, which is characterized by openness and inclusiveness.

Therefore, the green road in South China should meet the requirements of convenient and diversified integrated intelligent services.

\section{Connotation of green highway}

The green road should be based on the ecological principle and adhere to the concept of sustainable development. Up to now, there are more than ten definitions of green highway, which have gone through the development from single index to multiple indexes, from single aspect index to multi-level index, from single stage index to life cycle index, and constantly improved to move forward, meeting people's cognitive process of transformation and upgrading of green highway and people's potential requirements for a better life. The development of green road is not only an important measure of China's strategic deployment in the new era, but also the necessity of sustainable development of the industry and society.

According to the guidance on the implementation of green highway construction and the technical requirements for green traffic facilities assessment Part 1: green highway, The definition of green road refers to "on the basis of sustainable development, under the guidance of innovative, coordinated, green, open and shared new concepts, in the whole life cycle of road design, construction, maintenance and operation, maximize the realization of resource saving (land saving, water saving and material saving),energy conservation and emission reduction, environmental protection, focus on construction, operation, management quality improvement and operation efficiency improvement, provide people with safe, comfortable, convenient and beautiful driving environment and harmonious coexistence with nature". This definition mainly includes five aspects:

The first aspect is the concept of sustainable development, which is to meet the needs of the present generation without endangering the needs of future generations. The construction and development of the highway need the guidance of the concept of sustainable development, and at the same time, it should be promoted to the level of innovation, coordination, green, opening and sharing. Only in this way, can the green highway truly sustainable development.

The second aspect is the concept of "life cycle". The life cycle of highway includes planning, design, construction, maintenance, operation and maintenance, transformation, demolition, recycling and other aspects. It mainly emphasizes the sustainable impact of human construction activities on ecology, environment and resources in time.

The third is to emphasize "saving resources and energy 
to the maximum extent, protecting the environment and reducing pollution". That is to say, it is emphasized to save land resources, water resources, energy, materials and environment in the process of highway construction and operation.

The fourth aspect is the improvement of service, "bringing safe, comfortable, convenient and beautiful service", which not only requires the improvement of the quality of the road itself, but also potentially requires the improvement of humanized intelligent service.

The fifth aspect is that the green road should "live in harmony with nature", and the ultimate goal of developing green road is to realize the harmonious unity of human, road and nature.

\section{Composition of green highway assessment}

The evaluation of anything can't get rid of its stage. In the new era of socialism with Chinese characteristics, the main contradiction has been transformed into the growing demand for a better life. People are bound to have a more comprehensive evaluation requirements for all kinds of things at present. For the road infrastructure, people are also changing from the traditional qualification rate to higher requirements such as satisfaction and comfort, and from the traditional road to the green road. However, at present, all kinds of assessment methods of green road are single and general, which are mainly used to meet the needs of engineering projects. The assessment research is aimed at some stages and conventional indicators of the whole life cycle of Green Road, and there is a lack of scientific, systematic and comprehensive green road assessment system covering the whole life cycle.

This paper divides the green road assessment system into three parts: green design assessment index system, green construction assessment index system and green maintenance assessment index system. The three-stage evaluation system complements each other. It can not only evaluate each stage of the road separately, but also comprehensively evaluate the whole green road construction, so as to guide the design, construction and maintenance of the whole life cycle of the green road, comprehensively improve the construction level of the green road, and move forward to a powerful transportation country.

The evaluation index system of green design includes seven secondary indexes: green planning, land saving and land resource utilization, water saving and water resource utilization, material saving and material resource utilization, energy saving and energy utilization, environmental protection and service improvement; The green construction evaluation index system includes six secondary indexes: land conservation and land resource utilization, water conservation and water resource utilization, material conservation and material resource utilization, energy conservation and energy utilization, environmental protection and service improvement; The green maintenance evaluation index system includes six secondary indexes, including land conservation and land resource utilization, water conservation and water resource utilization, material conservation and material resource utilization, energy conservation and energy utilization, environmental protection and service improvement, as shown in Figure 1.

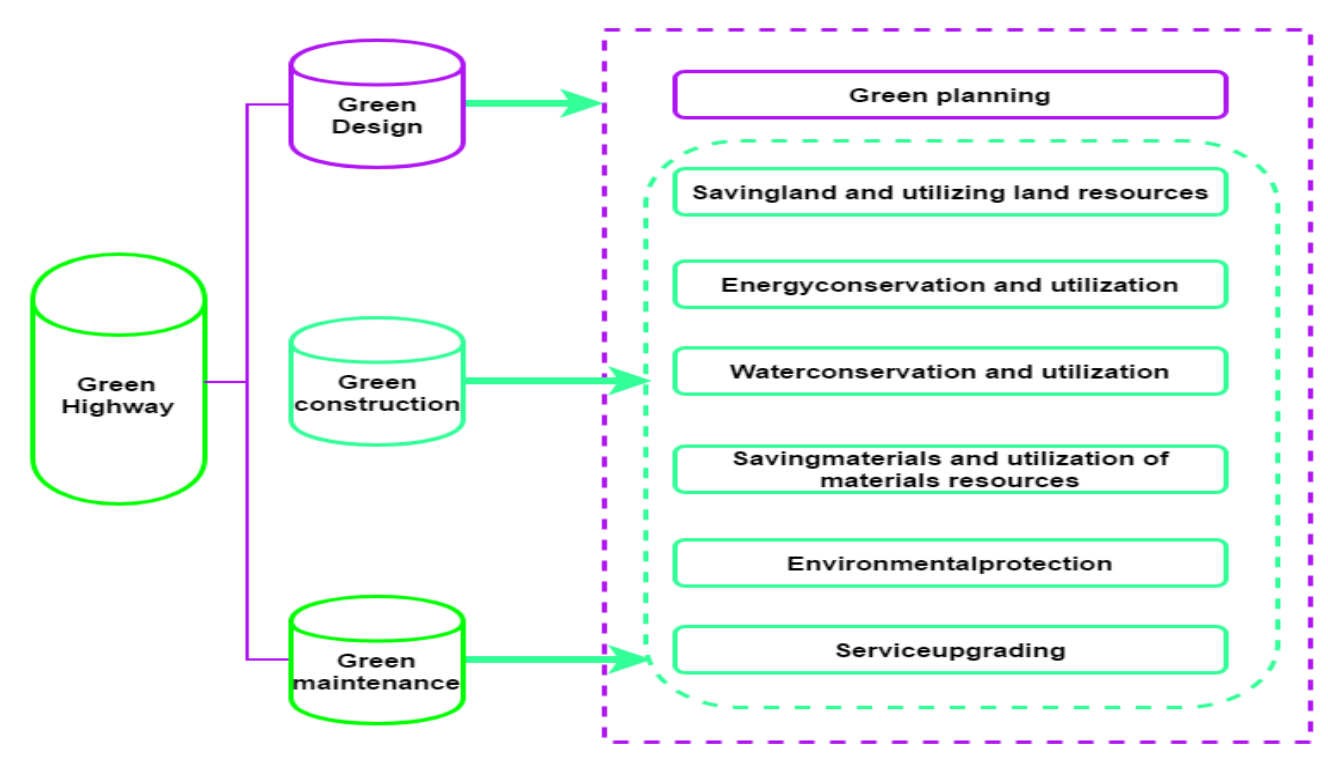

Figure 1. Composition of Life Cycle Green Highway

\section{Evaluation index system of green highway}

In order to further study the green highway evaluation system, this paper, from the perspective of the whole life cycle, combines the current affairs policy, the successful experience of typical green highway construction demonstration projects, "four new technologies" and many years of highway construction consulting experience, has decomposed or integrated the composition 
of green highway in Figure 1 form a life cycle index system. which is composed of three first-class indexes, 19 second-class indexes and 108 third-class indexes, specifically seven second-class indexes of green highway design evaluation, 39 third-class indexes of design evaluation, six second-class indexes of green highway construction evaluation, 39 third-class indexes of construction evaluation, six second-class indexes of Green Highway Maintenance Evaluation and 30 third-class indexes of Maintenance Evaluation, as shown in Table 1.

Table 1. Evaluation Index System of Green Highway

\begin{tabular}{|c|c|c|}
\hline First level index & Second level index & Third level index \\
\hline \multirow{32}{*}{ Green Design } & \multirow{3}{*}{ Green planning } & strategic planning \\
\hline & & Special fund planning \\
\hline & & Publicity and training plan \\
\hline & \multirow{12}{*}{$\begin{array}{l}\text { Saving land and } \\
\text { utilizing land resources }\end{array}$} & Route selection for land saving \\
\hline & & Balance design of filling and excavation \\
\hline & & Reasonable setting of borrow and spoil ground \\
\hline & & Reasonable design of bridge and tunnel instead of road \\
\hline & & Rational design of slope \\
\hline & & Interchange optimization design \\
\hline & & Reasonable layout of facilities along the line \\
\hline & & Overall utilization of collinear resources \\
\hline & & Permanent and temporary design \\
\hline & & Permanent design of access road and Bridge \\
\hline & & Permanent design of other temporary works \\
\hline & & Temporary land restoration design \\
\hline & \multirow{7}{*}{$\begin{array}{l}\text { Energy conservation } \\
\text { and utilization }\end{array}$} & Energy saving route selection design \\
\hline & & Energy saving speed design \\
\hline & & Combination design of horizontal and vertical lines for energy saving \\
\hline & & Energy saving design in construction period \\
\hline & & Energy saving design of highway auxiliary facilities \\
\hline & & Energy saving design of tunnel lighting, ventilation and monitoring \\
\hline & & Develop energy saving evaluation index \\
\hline & \multirow{4}{*}{$\begin{array}{l}\text { Water conservation and } \\
\text { utilization }\end{array}$} & Water saving for greening \\
\hline & & Water saving in service area \\
\hline & & Water saving planning during construction \\
\hline & & $\begin{array}{l}\text { Planning and design of comprehensive utilization of rainwater, waste water } \\
\text { and groundwater }\end{array}$ \\
\hline & \multirow{3}{*}{$\begin{array}{l}\text { Saving materials and } \\
\text { utilization of materials } \\
\text { resources }\end{array}$} & Use of local materials \\
\hline & & Recycling of waste materials \\
\hline & & Construction material saving measures \\
\hline & \multirow{3}{*}{$\begin{array}{l}\text { Environmental } \\
\text { protection }\end{array}$} & overall design \\
\hline & & Social and environmental protection \\
\hline & & Ecological environment protection \\
\hline \multirow{6}{*}{ Green Design } & \multirow{4}{*}{$\begin{array}{l}\text { Environmental } \\
\text { protection }\end{array}$} & Prevention and control of environmental pollution \\
\hline & & Greening design \\
\hline & & Landscape design \\
\hline & & Water and soil conservation \\
\hline & \multirow{2}{*}{ Service upgrading } & Improvement of construction quality \\
\hline & & Improvement of intelligent service \\
\hline
\end{tabular}




\begin{tabular}{|c|c|c|}
\hline First level index & Second level index & Third level index \\
\hline & & Improvement of green facilities \\
\hline \multirow{39}{*}{ Green construction } & \multirow{10}{*}{$\begin{array}{l}\text { Saving land and } \\
\text { utilizing land resources }\end{array}$} & Reasonable division of bid sections \\
\hline & & Combination of permanent and temporary facilities in construction site \\
\hline & & Land saving layout of borrow area \\
\hline & & Land saving layout of spoil ground \\
\hline & & Land saving layout of station facilities \\
\hline & & Land saving utilization of construction access road \\
\hline & & Combined use of temporary works \\
\hline & & Topsoil management \\
\hline & & Strengthen the protection of land resources \\
\hline & & Special inspection system for land saving measures \\
\hline & \multirow{6}{*}{$\begin{array}{l}\text { Energy conservation } \\
\text { and utilization }\end{array}$} & Energy saving of equipment \\
\hline & & Energy saving of resident construction \\
\hline & & Energy saving in station construction \\
\hline & & Process energy saving \\
\hline & & Technical energy saving \\
\hline & & Strengthen construction energy conservation management \\
\hline & \multirow{4}{*}{$\begin{array}{c}\text { Water conservation and } \\
\text { utilization }\end{array}$} & Strengthen water-saving organization and management \\
\hline & & Recycling of rainwater and underground precipitation \\
\hline & & Comprehensive utilization of waste water and sewage \\
\hline & & $\begin{array}{l}\text { Water saving and moisture preserving technology for concrete pavement } \\
\text { and base course }\end{array}$ \\
\hline & \multirow{6}{*}{$\begin{array}{l}\text { Saving materials and } \\
\text { utilization of materials } \\
\text { resources }\end{array}$} & Scientific material management \\
\hline & & Material saving utilization of process and technology \\
\hline & & Utilization of waste materials \\
\hline & & Comprehensive utilization of tunnel slag \\
\hline & & Adopt new materials \\
\hline & & Strengthen the quality management of construction process \\
\hline & \multirow{10}{*}{$\begin{array}{l}\text { Environmental } \\
\text { protection }\end{array}$} & Ecological environment protection \\
\hline & & Water environment protection \\
\hline & & Protection of acoustic environment pollution \\
\hline & & Air pollution protection \\
\hline & & Rock mining and dust control \\
\hline & & Solid waste treatment \\
\hline & & Social and environmental protection \\
\hline & & Protection of cultural relics \\
\hline & & Restoration of environmental damage \\
\hline & & Landscape greening \\
\hline & \multirow{3}{*}{ Service upgrading } & Improvement of construction quality \\
\hline & & Improvement of intelligent service \\
\hline & & Improvement of green facilities \\
\hline \multirow{4}{*}{ Green maintenance } & \multirow{4}{*}{$\begin{array}{l}\text { Saving land and } \\
\text { utilizing land resources }\end{array}$} & Optimization of highway reconstruction and expansion plan \\
\hline & & Reduce land damage during operation \\
\hline & & Post evaluation of land conservation and utilization \\
\hline & & Maintenance and management of reclaimed soil \\
\hline
\end{tabular}




\begin{tabular}{|c|c|c|}
\hline First level index & Second level index & Third level index \\
\hline & & Recycling of abandoned roads and temporary land \\
\hline & \multirow{6}{*}{$\begin{array}{l}\text { Energy conservation } \\
\text { and utilization }\end{array}$} & Energy saving of tunnel \\
\hline & & Energy saving of toll station \\
\hline & & $\begin{array}{l}\text { Energy saving in service area, management office area and maintenance } \\
\text { area }\end{array}$ \\
\hline & & Energy conservation of monitoring facilities \\
\hline & & Energy saving maintenance technology \\
\hline & & Energy conservation management system \\
\hline & \multirow{4}{*}{$\begin{array}{l}\text { Water conservation and } \\
\text { utilization }\end{array}$} & Water saving irrigation technology \\
\hline & & Water saving greening plants \\
\hline & & Water saving greening materials \\
\hline & & Water saving in service area, management area and maintenance area \\
\hline & \multirow{4}{*}{$\begin{array}{l}\text { Saving materials and } \\
\text { utilization of materials } \\
\text { resources }\end{array}$} & Recycling management \\
\hline & & Utilization of preventive maintenance technology \\
\hline & & Scientific management and flexible maintenance \\
\hline & & Material saving system management \\
\hline & \multirow{8}{*}{$\begin{array}{l}\text { Environmental } \\
\text { protection }\end{array}$} & Environmental protection management system \\
\hline & & Water environment protection \\
\hline & & Protection of acoustic environment pollution \\
\hline & & Air pollution protection \\
\hline & & Disposal of solid waste \\
\hline & & Ecological environment protection \\
\hline & & Create green service area \\
\hline & & Ecological restoration of built roads \\
\hline & \multirow{3}{*}{ Service upgrading } & Improvement of construction quality \\
\hline & & Improvement of intelligent service \\
\hline & & Improvement of green facilities \\
\hline
\end{tabular}

\section{Conclusion}

From the perspective of life cycle, combined with current affairs policy, sustainable green concept and successful experience of typical demonstration projects, this paper analyzes and studies the green highway, and draws the following conclusions:

First, The definition of green road refers to "on the basis of sustainable development, under the guidance of innovative, coordinated, green, open and shared new concepts, in the whole life cycle of road design, construction, maintenance and operation, maximize the realization of resource saving (land saving, water saving and material saving),energy conservation and emission reduction, environmental protection, focus on construction, operation, management quality improvement and operation efficiency improvement, provide people with safe, comfortable, convenient and beautiful driving environment and harmonious coexistence with nature."

Second, the green road evaluation system is divided into three parts: green design evaluation index system, green construction evaluation index system and green maintenance evaluation index system. The three-stage evaluation system complements each other. It can not only evaluate each stage of the road separately, but also comprehensively evaluate the whole green road construction.

Third, the whole life cycle green highway index system consists of three first-class indexes, 19 secondclass indexes and 107 third-class indexes, including seven second-class indexes of green highway design evaluation, 39 third-class indexes of design evaluation, six secondclass indexes of green highway construction evaluation, 39 third-class indexes of construction evaluation, six 
second-class indexes of green highway maintenance evaluation and 30 third-class indexes of maintenance evaluation.

Fourth, the three-stage evaluation index system of green road proposed in this paper will be further improved through modeling and empowerment, providing construction guidance for the design, construction and maintenance of green road in South China mountain area.

\section{Reference}

1. Chen Hong, Liang Li-jie, Yang Cai-xia. Ecological view of sustainable development highway construction for [J]. Journal of Chang'an University (Natural Science Edition), 2004,24 (1): 69-71

2. Zhang Qin. Research on assessment of green highway based on sustainable development concept [D]. Chongqing: Chongqing JiaoTong University, 2011

3. Wang Ji, Zhang Yi, Chen Shao-hui. Green LowCarbon Highway Construction Based on Life Cycle: Case Study of Maliuwan-Zhaotong Green LowCarbon Highway Construction in Yunnan Province [J]. Transportation Standardization, 2014,42 (3): 2730

4. Li man-liang, Zheng Chen, Wang Zhao-hui, et al. Evaluation index system of green ecological city road $[\mathrm{J}]$. Journal of traffic transportation engineering, 2015,15 (2): 10-21 